\title{
Emigration from the Perspective of the School-to-Work Transition in Bulgaria*
}

\author{
RUMIANA STOILOVA** \\ Institute for the Study of Societies and Knowledge, \\ Bulgarian Academy of Sciences, Sofia \\ ELITSA DIMITROVA \\ Institute for Population and Human Studies, \\ Bulgarian Academy of Sciences, Sofia
}

\begin{abstract}
The aim of this article is to analyse the extent to which differences between young people's education, employment status, and social background can explain the differences in their emigration intentions and actual experience with emigration. The goal is to create a profile of youth with emigration experience and examine the interrelation between two transitions, from education to work and from youth into adulthood, as measured by the degree of independence from parents, and also to investigate social inequalities among people with emigration experience in the transition from education to finding a first job. The analysis is based on theories of the individual life-course transition and social status theories. The empirical data were gathered from a representative survey conducted in Bulgaria in 2014 that focused on young people aged 15-34 who had left education within the previous five years. The results show that young people from large families with many siblings more often have emigration intentions and that previous emigration experience is the strongest predictor of emigration intentions. Emigration intentions are also more likely among people who have emigrated and later returned and ended up economically inactive. This fact is important in understanding the large number of young people who are not in education or employment (NEETs) in Bulgaria.
\end{abstract}

Keywords: emigration intentions, emigration behaviour, school-to-work transition, social inequalities

Sociologický časopis/Czech Sociological Review, 2017, Vol. 53, No. 6: 903-933

https://doi.org/10.13060/00380288.2017.53.6.380

\footnotetext{
* Acknowledgement: This article was prepared under the NEGOTIATE project, which received funding from the European Union's Horizon2020 research and innovation programme under grant agreement no. 649395.

** Direct all correspondence to: Rumiana Stoilova, Institute for the Study of Societies and Knowledge, Bulgarian Academy of Sciences, Sofia, Bulgaria, e-mail: rumiana.stoilova@ gmail.com.
}

C Sociologický ústav AV ČR, v.v.i., Praha 2017 


\section{Introduction}

Emigration has been an important focus for researchers in Bulgaria since 1989. Mancheva and Troeva [2011: 23] have noted that during the transition period Bulgaria was predominantly a country of intense emigration, with a high tendency towards transit migration, relatively small immigration flows, and a modest inflow of refugees. A recent World Bank report ranked Bulgaria, together with Albania, Armenia, and Bosnia and Herzegovina, among the top ten emigration countries in 2013 [Migration and Remittances Factbook 2016: 44]

There are several factors that have made emigration easier for young people: the equalisation of educational standards and the introduction of a foreign language course into the curriculum at the basic education level since 2000; ${ }^{1}$ the elimination of visa restrictions on travel for Bulgarian citizens in EU countries (2001); Bulgaria's joining the European Union in 2007 and the removal of restrictions to work within the EU (2014). Since the global financial crisis, youth unemployment has increased alarmingly in Bulgaria, like in many other European countries. Bulgaria has been among the EU countries with a relatively large share of unemployed young people: $28 \%$ in 2012 , decreasing to $16.70 \%$ by 2016 . Another alarming labour market indicator for youth in the country is the proportion of young people who are not in education, employment, or training (NEET) $(19.3 \%$, the highest percentage among EU countries, ranking Bulgaria last, in 27th place, according to this indicator) ${ }^{2}$ [Eurofound 2016: 28; Tamesberger 2015].

At a European level the debate among scholars about the NEET group has already identified "those who have discovered "alternative ways of living" within the informal and illegal economies' [Eurofound 2016]. Moving back and forth between seasonal work and returning to the home country may be seen as a useful option in the school to work transition. According to data from the European Social Survey, the chances of young people with lower than secondary education finding work with a permanent contract in Bulgaria are much poorer than the chances of young Bulgarians with complete secondary and higher education, but are worse in a comparative international context. The chances of young people with basic education finding a first permanent full-time job is assessed to be low by $87 \%$ of respondents in Bulgaria, $81 \%$ in Hungary, and $71 \%$ in Poland, but by considerably fewer respondents in Great Britain and Germany (51\%) [Stoilova

\footnotetext{
${ }^{1}$ In the basic education system, studying a foreign language is obligatory starting from second grade and a second Western language after fifth grade. Bulgarian diplomas are recognised in EU countries in accordance with Article 47 of the EU Treaty, which establishes the obligation for mutual recognition of diplomas, certificates, and other qualifications. Directive 2005/36/EC of the European Parliament and of the Council requires the recognition of professional qualifications.

2 The term NEET or NEETs is used to describe young people (15-29) who are not in employment, education, or training. In 2015 the NEET population aged 15-24 in Bulgaria was $19.3 \%$, while the average for the EU-28 is 12\% [Eurofound 2016: 36-40].
} 
and Haralampiev 2010]. For low-qualified Bulgarians in Western Europe the wage levels, for the same work, are higher than in Bulgaria and the wage differences motivate some of them to search for a job abroad.

It is possible to identify both positive and negative effects in the emigration of young people. The negative effects include a worsening of the age structure of the Bulgarian population [Marinov 2007: 48]. The share of people over the age of 65 in Bulgaria has grown from 13.2\% in 1990 to 20.4\% in 2015 [Statistical Yearbook 2016]. But positive effects have also been identified, such as a decrease in unemployment in the emigrants' country of origin. And like in other emigration countries, the remittances sent home to Bulgaria by migrants are at a very significant level [World Bank 2012].

In 2015 Bulgaria was among the top ten remittance recipient countries (billions of USD). Remittances are estimated to be as much as 1.8 billion USD [Migration and Remittance Factbook 2016: 45]. Financial transfers home by migrants both to support family and for savings purposes play a major role in economic development and are an important factor in poverty reduction in the country [Minchev and Boshnakov 2006a; 2006b]. The same authors [ibid. 2006a] also found that remittances to Bulgarian households are used mainly for consumption but also for 'non-altruistic', profit-oriented, purposes (to run a business, for savings, etc.).

For young people there is more than just a financial dimension to temporary and long-term migration experience, as the experience also involves 'social remittances' [Levitt 2001]. Young migrants bring with them social remittancesdefined as ideas, know-how, practices, and skills-that shape their integration into the host society, and they also send back social remittances that shape their life course perspectives in their country of origin. Markova [2010] explored the economic and social effects of emigration from Bulgaria and found some of the negative social effects of emigration to be the growing instability of families, the growing number of children left behind, family separations, and the abandonment of old people. However, she also found that young people's emigration could have strong positive effects, such as improving their language and other skills, knowledge, and labour market experience.

Considering how much emigration exceeds immigration in Bulgaria, and considering the high rate of youth unemployment and of young people who are NEET, it is important to study the link between emigration and the employment experience of young people. Below we intend to investigate to what extent young people see work abroad as an option for gaining entry into the labour market after they leave formal education. In the transition from leaving formal education to finding a stable job young people differ significantly with respect to the resources they can draw on, such as completed education (human capital), family support and networks (social capital), and the socio-economic characteristics of the background family (social background). Our aim is to analyse the extent to which the differences between young people's education, employment status, and social background can explain the differences in their emigration intentions and actual experience. 


\section{Theoretical framework}

The concepts of transitions and trajectories are fundamental to life course studies. Transitions are defined as changes in state that are more or less abrupt. 'Relating individual life courses to their temporal moments, the speed and sequence of events in the life of an individual (micro-level) to the dynamics of the social structures and institutions (macro/meso level) is the central idea of the life course approach.' [Wingens et al. 2011: 6] The findings of life course studies could serve as the basis for designing policies that are preventive rather than reactive to various social problems such as youth unemployment or the NEETs phenomenon. Changes in institutional regulations and mechanisms lead to changes in individual life trajectories and choices, and, vice versa, changes in individual plans and decisions lead to changes in social structures and institutions [Kley 2011: 469-486].

Research on the transition from education to first job shares a number of features with life course studies in that in both cases the transitions between different domains of an individual's life are the subject of analysis [Mayer 2009: 413-433]. People's lives are shaped and develop in a collective context. For instance, the analysis presented in this article takes into account the individual choices made by young people (ages 15-34) in the Bulgarian post-socialist context after accession to the EU in 2007 and during the recent global economic crisis (2008-20012).

Individual decisions are shaped largely in accordance with social position within the social structure [Kogan 2012: 701-703; Robert and Saar 2012: 742-754]. In making the transition from education to a first full-time job, young people have unequal opportunities. These chances depend on their social origin and the ability of their parents to support and motivate young people to get a longer education. The human capital model is considered the dominant paradigm in immigrant labour market integration research [Kogan et al. 2011a]. It is expected that low-skilled people would probably be more willing to accept work in the informal economy than better educated and skilled migrants. Employers who hire low-skilled migrants and do not invest additional time and resources in their training may be expected to be more inclined towards short-term labour relations. Conversely, highly skilled migrants are more likely to work in the regulated than the grey economy and to work under contract for longer periods of time.

Higher levels of education, the acquisition of professional skills that are in demand, and the development of foreign language skills give young people better chances of finding work in foreign countries. Low social position in the social structure of the home society is very often accompanied by a lower level of education, earlier departure from the education system, and poor language skills. All this makes emigration less stable and it is more likely for a young person with lower education to stay and work abroad for shorter period than to be 
stably integrated into the labour force in the host country. Poor knowledge of the host country's language (regardless of the method of measurement-objective or subjective) is observed to have a limiting effect on migrants' integration into the labour market in Germany [Kogan et al. 2011b].

The emigration option is one possible individual life trajectory in the transition from education to first job. ${ }^{3}$ Studying the role of emigration in transitions within the individual life course has an added trans-national, so that it is necessary to focus on the passage from a given institutional context in which the individual's life has developed and in which a certain education has been acquired to a different institutional and national context of the labour market [Söhn 2011: 28; Noelke et al. 2012: 704-716].

In addition to transition and social status theories, this paper draws on migration theories and particularly on labour emigration. Explanations of migration behaviour in the literature emphasise either micro- or macro-level factors [De Jong and Gardner 1981]. Micro-level analysis focuses on individual migration decisions, while the macro-level approach analyses the aggregate characteristics of migration as a demographic process and explains these characteristics from the perspective of their macro-level causes and consequences [Hagen-Zanker 2008]. The macrolevel approach accounts for the interdependence between migration and certain socio-economic and environmental characteristics of a geographic area [Cadwallader 1989]. From a macro-level perspective, migration can be seen as a result of geographic and regional differences in the supply and demand of labour, i.e. as the movement of individuals from economically less developed areas to areas with better economic conditions (low unemployment, higher salaries) [Hagen-Zanker 2008]. Regional differences in wage levels between Western and Southeast Europe determine that countries where wages are higher, where there is labour force demand in sectors like construction, services, tourism, and home care, are attractive for young, low-qualified Bulgarians (pull factors). In the present analysis, we also pay attention to national-level imbalances between regions, in that the northwest region of the country is exceptionally poor in both the national and European context (push factors). On the other hand, at the national level, the southwest region of Bulgaria has the best indicators for the education and employment of young people, including wages [Stoilova 201]. This analysis therefore includes indicators on place of residence as explanatory factors for both emigration intentions and the actual experience of working abroad. The explanatory analysis takes into account the unequal development of employment within the regions and in the capital city compared to other kinds of settlement in the country.

A micro-level approach explores how people choose between alternatives (i.e. to migrate to or to stay in a certain place of residence) [Cadwallader 1989;

${ }^{3}$ For a definition of the sequences in the transition from education to first job, see Brzinsky-Fay [2007: 409-422]. 
Haug 2008; Klabunde and Willekens 2016: 73-97]. The main unit of analysis to describe and explain migration processes is the individual and/or the household [De Jong and Gardner 1981; Neto and Mullet 1998]. This approach goes beyond a numerical count and aggregation of events and takes into account various social factors that influence the migration decision. The micro-level approach fits best with migration-related life course research [Wingens et al. 2011].

The interaction between active subjects and the social structure is fundamental to studies on transitions in the individual's life course [Dimitrova and Kotzeva 2013: 91-117]. The matching between micro and macro approach requires a focus on the importance of individual characteristics for transition events. Two individual characteristics are focused on in this analysis: the role of gender and ethnicity in emigration intensions and the behaviour of young Bulgarians. Family status is also considered an important determinant for emigration. For the macrolevel perspective, we see geographical region and place of birth as an important determinant for both internal and external migration.

A deeper interest in and analysis of the interrelations between individual action, the individual's transition history, and their embeddedness in society require specific kinds of empirical data focusing on subjective attitudes and actual behaviours. This article explores the labour emigration of young people in Bulgaria both from the perspective of their intentions to make the transition from education to the labour market by choosing to start working abroad and their actual experience of it. This combination of both types of analyses of migration intentions and actual migration behaviours of young people in the process of leaving formal education and entering the labour market has rarely been done.

\section{Social context}

Young people are the people who emigrate most. There are diverse trends in different age groups and their corresponding emigration behaviours. According to the results of a survey called 'Migration and the Migration Behaviour of the Population', conducted in parallel with the last population census in 2011, with increasing age, short stays abroad (from 3 to 6 months) decrease, and longer stays (more than 6 months) increase [Migration and Migration Behaviour of the Population 2012: 21]. Among respondents aged 15 to 19 years, 21.7\% identified work as the main reason for traveling abroad. Among people in the 20-39 age group, the percentage is three times higher (61.9\%). Thus, the data reveal that among young people the search for work is an important reason to leave the country. The prevailing reasons for returning to the country of origin are the end of the work contract abroad (36.5\%) and re-joining family (24.1\%) [ibid.: 22].

The existing data reveal also significant gender differences in the reasons for emigration: $65.0 \%$ of men and $49.4 \%$ of women indicate work as the main reason for emigrating [ibid.: 29]. Research interest in gender differences among 
emigrants from Central and Eastern Europe has grown since 2001, when the International Organization for Migration began preparing annual reports on the gender mainstreaming strategy [Rangelova et al. 2006: 43-66]. In the next part of the paper, we will also try to show the extent to which there are gender differences among potential young emigrants and actual returnees in Bulgaria and how the actual experience of emigration and emigration intentions differ between young men and women.

Some studies show that there have been gender differences related to emigration throughout the period of social transformation in Bulgaria. A study conducted by Stoilova and Slavova [2006] revealed that a stronger tendency in the younger generation of women in Bulgaria to value their emigration experience, because the middle generation of women find it harder to integrate into a different cultural environment, even when they have achieved professional success. According to the same study, emigration for the purpose of career and professional development is much more common among middle-class women (defined primarily on the basis of higher education) than women from lower social strata, including those in the category of the 'working poor'. Women with secondary education or even with additional post-secondary, non-tertiary level education are more likely to take unqualified jobs abroad, such as caring for older people or small children. The conclusions in the cited study were reached using the qualitative method of in-depth life course interviews. In the present analysis, gender differences in emigration experience and the intentions of young people will be analysed on the basis of quantitative data. Gender differences in young people's emigration intentions and experience will be analysed in their intersection with education, social origin, and place of residence.

According to another study conducted in Bulgaria by Mitev and Kovacheva [2014], the emigration intentions of high school students and university students are stronger than the young people who have completed their education. With regard to motivation for potential emigration, it is important to note that highly educated people most often consider emigration a means to upward social mobility. Pursuit of a professional career is the most significant motive in the plans of university students to leave the country, along with the possibility of residing in a country with a higher standard of living. Social mobility is also frequently mentioned by students with higher academic achievements. According to the survey results, 'among those intending to emigrate, the majority have grades around excellent, while among those who have not thought of emigrating, this category amounts to a third of respondents' [Mitev and Kovacheva 2014: 185]. Better-paid work is cited as the most important emigration motive primarily by unemployed people group, followed by the employed, and, thirdly, by university students. In our analysis, in order to characterise the sociological profile of young people with experience working abroad, we also included a regional aspect, looking at the emigration of young people from different regions and different places of residence. 
To continue our analysis, it is important to know to what extent the emigration of young people from Bulgaria has specific national features and to what extent it is a reflection of processes typical for emigration from all postcommunist countries to Western Europe. A study on migration since 1989 for Poland, Hungary, the Czech Republic, and Slovakia states that the dominant pattern of migration until recently has been permanent one-way migration. The new characteristic of migration in the 1990s is the predominance of 'short-term, circulatory movements backwards and forwards across borders. This would be better termed mobility than migration' [Wallace 2002: 604]. A comparative study on migration flows between Eastern and Western Europe shows that in the recent period there has been a strong trend of return migration to Eastern Europe. In Poland, Hungary, Latvia, Lithuania, and Romania, the returnees are most often male, young, not married, with secondary or higher education [Martin and Radu 2009]. The chances of circular mobility and the duration of work abroad depend on the educational status of migrants.

The 'brain-drain' is a problem for all transformation countries. An empirical survey in the four Visegrad countries, Poland, Hungary, Slovakia and the Czech Republic, focusing mainly on migration potential [Fassmann and Hintermann 1997] showed that almost half of those who in principle have a positive view of migration have a university degree or are qualified for university admission; one-third have vocational education and $14 \%$ have only compulsory education. An important conclusion drawn from existing emigration research that includes Bulgaria is that less educated migrants are usually the ones who are first to return to their country of origin [Zaiceva and Zimmermann 2012]. By focusing on the impact of the economic recession (2008-2012) on migration flows, Zaiceva and Zimmerman [2012] show that the educational characteristics of the returnees vary. In Bulgaria, it is more likely for the returnees to have a lower level of education, unlike the returnees in Central European countries (the Czech Republic, Slovakia and Hungary). In Bulgaria (together with Romania and Latvia), the proportion of returnees who were unemployed while they were abroad is greater than Central European countries. The study also reveals that in Central and Eastern European countries, the former migrants also commonly have the intention to emigrate again. This results in circular migration, which is driven by the fact that the accumulated experience and skills of returnees make it more likely that they will go to live and work abroad again.

In many studies family status is a statistically significant predictor of emigration. For example, Vavrečková and Baštýř [2009: 25] point out that single people migrate more often than people who are married or cohabiting. The importance of the analysis that will be presented in the next parts of the article derives from the fact that few emigration studies on post-socialist countries include Bulgaria or other countries from Southwest Europe. There are few studies that focus on episodes of work abroad as part of the transitions of young people from 
education to their first significant job ${ }^{4}$ and the number of studies that do so from a sociological perspective is even smaller. Here we apply a sociological approach to emigration, in which the emphasis is placed on social background factors and inequalities among young people who decide to work abroad in the course of their school to work transition.

\section{Data, hypothesis, methods of analysis and limitations}

Studies on the transitions that occur throughout an individual's life course require longitudinal empirical data. For instance, research can investigate whether a person is able to find permanent employment relatively quickly or more slowly, and theg sequences of change in insecure employment statuses [Kogan et al. 2011a]. In Bulgaria, this type of study is rarely done. One example of a longitudinal study that reconstructs the different stages of individuals' transitions in various domains is the Gender and Generations Survey, in which Bulgaria took part in 2004 and 2007. However, we also need data that cover the impact of the global financial crisis (2008-2012) on young people's migration behaviours, since research shows that in that period migration flows between Eastern and Western Europe intensified [Zaiceva and Zimmerman 2012].

This article is based on the School Leavers Survey of young people (aged 15-34) in Bulgaria. ${ }^{5}$ This survey uses retrospective data obtained using a detailed calendar of the education to work transitions made in during the five years after leaving formal education. Focusing on this five-year period it enbles a deeper analysis of two important transitions in youth: from education to work and, in less detail, the transition from childhood to adulthood.

The Transition from School to Work survey was implemented in Bulgaria from August 2013 to October 2014. Eligible respondents were citizens of Bulgaria aged 15 to 34 who had completed or stopped their education for the first time and for at least one year within the last five years (between January 2009 and January 2013). The interruption in education could not be due to maternity leave, serious

\footnotetext{
${ }^{4}$ The first significant job position is defined here in accordance with the accepted definition in the school-to-work transition literature [Kogan and Mueller 2003; Gebel and Noelke 2011]. Significant employment means a job that is held for at least six months and involves at least twenty working hours per week. It excludes apprenticeship and participation in a dual schema-study and work. Significant employment may also refer to unofficial and unregistered employment.

${ }^{5}$ The survey was conducted under the project 'Social Inequalities and Regional Differences in Transitions from Education to Work in Bulgaria' (http://www.schooltowork.bg) in partnership with the University of Basel and the Institute for the Study of Societies and Knowledge, Bulgarian Academy of Sciences, with financial support provided in the framework of Switzerland's Contribution to the Expanded European Union and by the Bulgarian Ministry of Science and Education.
} 
illness, national service, waiting for a certificate to get access to education at a higher level, or the decision to take a gap year or break period. A two-stage cluster sample structured by region and size of the settlement was employed. The total sample size was 2103, of whom $51 \%$ were men and $49 \%$ women. The age structure of the sample was as follows: $11 \%$ of the respondents were aged $15-19,59 \%$ were 20-24 years, 26\% were 25-29 years, and the final group, 30-34 years, made up 4\% of all respondents. The sample also included the main ethnic groups in society: $75 \%$ were Bulgarians by ethnicity, $17 \%$ Turks (the share of Turkish respondents is higher than their percentage in the Bulgarian population), 5\% Roma, and 3\% other ethnic minorities. In the sample, $14 \%$ of respondents were living in the capital Sofia, $26 \%$ in a big city, $30 \%$ in a small city, and $30 \%$ in a village.

For the main survey, three samples were drawn in total: one main sample, representative at the national level, $\mathrm{N}=1500$; one booster sample representative for the poorest region in the country (northwest region), $\mathrm{N}=300$; and one booster sample representative for the wouthwest region (the most prosperous region in the country; excluding Sofia-the capital city), $\mathrm{N}=300$. A two-stage cluster sample structured by region and size of the settlement was employed in both the main and the booster samples.

One limitation to the study is that it is designed to reflect the details of employment and educational activities of young people within the country. There is no detailed information about migration experience, about the sectors of employment for those working abroad, and about the employment sector those planning to leave the country to seek work abroad intend to work in. There is no detailed information about migration history across the life course since the sample covers the relatively short period (5 years) of the transition from education to stable employment among young people in Bulgaria. However, the question about the respondents' plans to leave the country and the reasons for these plans can be used to reconstruct potential emigration among young Bulgarians in the transition from education to work. The study includes also information about the experience of migration and the reasons for stays abroad longer than 6 months. This information allows us to partly reconstruct the migration experience of those respondents who have been abroad and returned to the country, i.e. it covers the returnees among the young Bulgarians, but we lack information on the migrants who are currently abroad.

Here we seek, on the one hand, to analyse the differences between young people with declared intentions to work abroad and young people who declare no interest in working abroad, and on the other hand, to study return migrants from the perspective of gender, age, the impact of human capital level (education), ${ }^{6}$

\footnotetext{
${ }^{6}$ We see one limitation of the questionnaire to be the absence of an indicator for the ability to speak/understand foreign languages. We asked respondents about their highest level of formal education attained and about their grades in math and Bulgarian language, as is done in the PISA tests.
} 
employment status, social origin (parent's employment status and ethnic origin), place of residence, and family situation, and compare them to young respondents with no experience of working abroad. It is important to establish whether young people returning from employment abroad are most often those with higher or lower levels of education. But is education perhaps a less important factor than the possibility of finding employment in their country? Answering this question is important for developing effective policies for retaining returning migrants in the country. The motivation for working abroad and the chances of finding work abroad are expected to differ among young people with different levels of education.

Our interest in this analysis is in less qualified young people, who see emigration as a way to find a job that is better paid abroad than in their home country (pull factors for work emigration intensions). We will try to identify to what extent there are differences based on young people's social status and if differences in emigration plans and experiences vary depending on whether the young people are secondary school graduates or university graduates, and employed or unemployed people. We will also try to outline the sociological profile of youth with the emigration experience and the specificities of the transition from education to work. The main research questions to be answered in this article are the following: To what extent do social status-based differences between young people explain the differences in their emigration intentions and in their actual emigration experience? What are the differences based on gender, age, place and region of residence between young people with or without experience of working abroad? We are interested in family status and family background, and the existence of many siblings as an indicator in Bulgaria of a poor social background and limited family resources, which could trigger the emigration of young people. We shall test the following hypotheses:

1. Emigration intentions are stronger among young people who are unemployed and inactive than among young people who are employed in their home country.

2. Previous emigration experience increases emigration intentions irrespective of level of education and employment status.

3. Secondary and higher education increase both emigration intentions and the likelihood of having actual experience with emigration.

4. Living in a place other than the capital city increases emigration intentions and (the likelihood of the emigration) experience.

5. Men have higher emigration intentions and emigrate more often than women, regardless of the level of completed education and employment status.

6. Young returnees are more likely to come from economically deprived families (a family with a low socio-economic status and many siblings).

The last hypothesis underlines the cumulative effect of various socio-economic characteristics of young people that increase their return to the country of 
origin. We expect that fewer resources lead to labour emigration as a strategy to escape material deprivation and socio-economic insecurity. However, emigration in this case is associated with a stay followed by a return to the home country as a result of having lower chances of finding a stable job abroad.

\section{Methods of analysis}

We use descriptive statistics and logistic regression models here to explore emigration intentions and the experience of young people. In the logistic regression models, we take as the dependent variable the intention to emigrate as opposed to no intention to emigrate. The same model is applied for actual experience with emigration as opposed to no experience with work abroad. The independent variables included in the models are: age, gender, educational level, and employment status of the respondent; ethnicity, family status, number of children, place of residence, type of household the respondent lives in, parents' employment status, and number of siblings.

\section{Descriptive and multivariate analysis of labour emigration intentions and experience}

\section{Labour emigration intentions: descriptive statistics}

Emigration intentions are classed in the respective calendar data according to the status of the individuals in their transitions from education to employment immediately after finishing formal education, after finding their first significant job, and after becoming unemployed. In answer to the question whether they intend to seek work abroad after leaving education, $17 \%$ of respondents answered yes and $83 \%$ no. A significant gender difference was observed among respondents with respect to migration intentions: $63 \%$ of the men and only $37 \%$ of the women in the sample were planning to leave the country. The analysis shows also that $18 \%$ of the respondents ages $15-19$ have the intention to migrate. The highest percentage of potential migrants is recorded in the $20-24$ age group at $20 \%$. The percentage decreases in the higher age groups. The intention to work abroad also differs significantly between ethnic groups: $26 \%$ of young Roma respondents answered in the affirmative when asked if they were planning to leave the country to work abroad in the next six months. Among young respondents with a Turkish ethnic background, $21 \%$ said that they intended to work abroad in the near future. The intention to emigrate for work is lower among ethnic Bulgarians at $16 \%$. Young people with basic or a lower level of completed education are most likely to plan to go abroad for work (21\%), followed by those with completed secondary education $(18 \%)$, and those with higher education $(12 \%)$. The highest percentage of potential leavers is found among the respondents living in villages at $19 \%$. 
Among young people living in the capital Sofia, $10 \%$ were planning to leave the country. Married people are less likely to answer affirmatively about plans to leave the country in the near future to look for job (12\%). The highest percentage of potential migrants is recorded among people who are not married $(19 \%)$. Among childless respondents, $18 \%$ have plans to migrate, while among those who have children the percentage is lower $(12 \%)$. Unemployment status proved to be a very important push factor: $17 \%$ of currently unemployed respondents claimed that they would look for a job abroad, while $83 \%$ said they would not.

\section{Labour emigration experience: descriptive statistics}

In the sample, $17 \%$ of young people reported that they had experience with emigration after leaving formal education. The main purpose of emigration was related to work; $45 \%$ of young respondents had been abroad for at least one month in order to work (Table 4 in the Appendix). The next most frequent motive for staying abroad was family reasons (28\%) and tourism (23\%); $3 \%$ of the respondents were abroad for training or education.

Men made up the majority of respondents who were abroad for at least one month in order to work (10\%). The share of women is two times lower $(5 \%)$. There is a larger share of people in the 25-29 age group who worked abroad $(10 \%)$ than in the younger age groups (8\% among those aged 20-24 and 3\% among those aged 15-19). The percentage of returned migrants with an ethnic minority background (Turkish, Roma and other) is higher at 10\% compared to $7 \%$ of ethnic Bulgarians. The share of return migrants is higher among people with basic or lower education at $10 \%$. In the groups of respondents with completed secondary or higher education, the share of young people who worked abroad and returned is $7 \%$. The biggest group of return migrants are single $(61 \%)$ and without children (77\%). The share of young people who worked abroad and returned is highest among those who currently live outside the capital. Among peple who live in big/small cities it is 7\% and it is $9 \%$ among those living in villages, while for those who live in the capital the share is $6 \%$.

The average duration of young migrants' work in a foreign country ${ }^{7}$ varies depending on its consecutive place in the order of job transitions after leaving education. The first job abroad starts in the first 1-2 months after the end of education and continues for about one year. The duration of every consecutive job abroad, however, decreases (Table 5 and 6 in the Appendix). The start of a second

\footnotetext{
${ }^{7}$ We measured the time since leaving formal education until a job was found abroad. We obtained calendar data for 14 changes in the economic activity of respondents since leaving formal education. The duration periods for the length of time between leaving formal education and finding consecutive jobs abroad are calculated from this calendar.
} 
job abroad occurs, on average, about one year after the end of formal education. The third job abroad tends to be found in slightly less than a year and a half after the end of education, while the fourth and subsequent jobs abroad begin after a considerably longer period of time after the person left formal education in Bulgaria.

The analysis of the current employment status of the respondents who had their first job abroad after leaving formal education and returned to Bulgaria reveals that $33 \%$ of them had stable jobs at the time of the survey, $19 \%$ were still economically inactive, ${ }^{8} 20 \%$ were unemployed, $20 \%$ had unstable jobs, and 9\% were seasonal workers (Table 7 in the Appendix). This means that the accumulation of work experience abroad had a positive effect on only one-third of young returnees. A larger proportion of young people had who worked abroad and returned to Bulgaria faced difficulties finding a stable job in their home country.

\section{Results from regression analysis}

In order to analyse young people's emigration intentions, we asked the following question in the questionnaire: 'Do you plan to go to work abroad in the next six months?' Based on the answers to this question, we created a binary variable indicating positive and negative intentions to leave the country in the next six months. Binary logistic regression models have been used to measure the impact of various socio-demographic characteristics of respondents on the likelihood of positive or negative intentions to leave the country in search of work abroad.

The dependent variable in the model for labour emigration experience was constructed on the basis of two questions in the questionnaire. The first question was whether respondents had been abroad for at least one month after leaving formal education. The second question asked for the reasons for staying abroad. Based on the combination of these two questions, two groups of young people were distinguished: those who had worked abroad for at least one month after finishing their formal education and returned to Bulgaria (17\%), and those who had not worked abroad (83\%).

Table 8 and 9 in the Appendix present the descriptive statistics for the dependent and independent variables and the results of the logistic model. The control variables in the models are the following: age groups (15-24 and 25-34); gender; completed education of the respondent (primary or lower, secondary,

\footnotetext{
8 The economically inactive population refers to persons who were neither 'employed' nor 'unemployed' during the short reference period used to measure 'current activity'. This population comprises four groups: people enrolled in educational institutions; retirees; people performing family duties; other economic inactivity [Eurostat 1999].
} 
Table 1. Logistic regression models for emigration intentions and experience

\begin{tabular}{|c|c|c|c|c|}
\hline & \multicolumn{2}{|c|}{ Model 1} & \multicolumn{2}{|c|}{ Model 2} \\
\hline & \multicolumn{2}{|c|}{ Migration intentions } & \multicolumn{2}{|c|}{ Migration experience } \\
\hline & $\begin{array}{l}\text { Odds } \\
\text { ratio }\end{array}$ & $\mathrm{p}>\mathrm{z}$ & $\begin{array}{l}\text { Odds } \\
\text { ratio }\end{array}$ & $\mathrm{p}>\mathrm{z}$ \\
\hline Age 25 and older (compared to $15-24$ ) & 0.62 & 0.037 & 2.15 & 0.004 \\
\hline Female & 0.63 & 0.001 & 0.43 & 0.000 \\
\hline Other than Bulgarian ethnicity & 1.90 & 0.614 & 1.33 & 0.258 \\
\hline \multicolumn{5}{|l|}{ Education (primary or lower as ref.) } \\
\hline Secondary & 1.19 & 0.365 & 0.94 & 0.807 \\
\hline Higher & 1.19 & 0.580 & 0.47 & 0.052 \\
\hline \multicolumn{5}{|l|}{ Employment status (employed as ref.) } \\
\hline Unemployed & 1.44 & 0.011 & 1.14 & 0.526 \\
\hline Economically inactive & 0.64 & 0.060 & 1.70 & 0.045 \\
\hline $\begin{array}{l}\text { Previous emigration experience (no } \\
\text { experience as ref.) }\end{array}$ & 5.53 & 0.000 & - & - \\
\hline \multicolumn{5}{|l|}{ Family status (no partner ref.) } \\
\hline Cohabitation & 1.25 & 0.275 & 0.99 & 0.978 \\
\hline Married & 0.82 & 0.441 & 1.66 & 0.107 \\
\hline Have children (compared to childless) & 0.74 & 0.203 & 0.85 & 0.601 \\
\hline \multicolumn{5}{|l|}{ Place of residence (Sofia as ref.) } \\
\hline Large city & 1.97 & 0.004 & 1.12 & 0.711 \\
\hline Small city & 2.90 & 0.002 & 0.87 & 0.644 \\
\hline Village & 1.87 & 0.010 & 1.24 & 0.477 \\
\hline \multicolumn{5}{|l|}{ Household (lives with parents as ref.) } \\
\hline Lives in own dwelling & 0.93 & 0.722 & 1.48 & 0.126 \\
\hline Lives in rented dwelling & 1.23 & 0.270 & 1.71 & 0.024 \\
\hline $\begin{array}{l}\text { Father unemployed / econ. inactive / } \\
\text { no father (compared to employed father) }\end{array}$ & 0.99 & 0.942 & 1.10 & 0.624 \\
\hline $\begin{array}{l}\text { Mother unemployed / econ. inactive/ } \\
\text { no mother (compared to employed) }\end{array}$ & 0.86 & 0.319 & 1.22 & 0.346 \\
\hline \multicolumn{5}{|l|}{ Number of siblings (no siblings as ref.) } \\
\hline 1 sibling & 1.21 & 0.270 & 1.33 & 0.237 \\
\hline More than 2 siblings & 1.72 & 0.012 & 1.20 & 0.954 \\
\hline Constant & 0.09 & 0.000 & 0.05 & 0.000 \\
\hline Log likelihood & \multicolumn{2}{|c|}{-850.27} & \multicolumn{2}{|c|}{-517.17} \\
\hline Pseudo $\mathrm{R}^{2}$ & \multicolumn{2}{|l|}{0.091} & \multicolumn{2}{|l|}{0.049} \\
\hline Num. of observations & \multicolumn{2}{|l|}{2043} & \multicolumn{2}{|l|}{2043} \\
\hline
\end{tabular}

Source: School-leaver survey, 2014; authors' calculations. 
Table 2. The impact of region on experience with emigration and emigration intentions: results from the logistic regressions

\begin{tabular}{|c|c|c|c|c|}
\hline & \multicolumn{2}{|c|}{ Emigration experience } & \multicolumn{2}{|c|}{ Emigration intention } \\
\hline & Odds ratio & Sig. & Odds ratio & Sig. \\
\hline Northwest region & 1 & & 1 & \\
\hline North-central & 2.26 & ** & 1.31 & \\
\hline Northeast & 1.35 & & 1.10 & \\
\hline Southwest & 1.38 & & 1.02 & \\
\hline South-central & 1.33 & & 1.34 & \\
\hline Southeast & 1.01 & & 1.25 & \\
\hline
\end{tabular}

Note: ${ }^{* * *} \mathrm{p} \leq 0.01 ;{ }^{* *} 0.01<\mathrm{p} \leq 0.05 ;{ }^{*} 0.05<\mathrm{p} \leq 0.10$.

In the models we control for age, gender, number of children, marital status, ethnic origin, place of residence, completed education, number of brothers and sisters, type of household, employment status of the respondent, experience of temporary employment before leaving education, experience of significant employment after leaving education, education and employment status of parents.

higher education); the respondent's employment status in Bulgaria (employed, unemployed, economically inactive ${ }^{9}$ ); ethnicity (Bulgarian vs non-Bulgarian); family status (no partner, cohabiting, married); number of children (with or without children); place of residence (Sofia, large city, small town, village); type of household the respondent lives in (with parents, in own dwelling, in a rented dwelling with other people); social background based on father's and mother's employment status (employed vs unemployed, economically inactive ${ }^{10}$ ); and number of siblings (no siblings, one sibling, two or more siblings). In the regression model of migration intentions, we included an additional variable reflecting the impact of previous migration experience related to work abroad (with/without emigration experience related to work abroad).

The results of the models (presented in Table 1) of young people's intentions and emigration experience reveal the following. Respondents aged 25-34 are less likely to plan to work abroad compared to the reference group (young people aged 15-24). However, they have greater experience with emigration.

\footnotetext{
${ }^{9}$ Economic inactivity among young people refers to the following statuses: doing housework; on maternity/paternity leave; unable to work due to permanent disability or illness; NEET.

${ }^{10}$ Economic inactivity among parents includes the following statuses as possible answers to the question about the current employment status of father/mother: retiree, performing home duties; unable to work due to disability.
} 
Women are less likely to plan to leave the country in order to look for a job abroad than men (reference category) and have less experience with emigration. Family status and number of children do not have a significant impact on the intention or experience with emigration. Although the literature [Nivalainen 2004: 157-175; Boyle et al. 2008: 209-222] shows that family status and number of children are important determinants of migration intentions and behaviour, in our case the absence of statistically significant effect relates probably to the design of the study. The study was done only on young people (up to 34 years of age) after graduation (up to 5 years). Out of all the respondents, $67 \%$ were single and $80 \%$ had no children.

Respondents with emigration experience are much more likely to have plans to leave the country again to search for work abroad than people who don't have such experience.

Education does not have a significant impact on emigration intentions. However, education is statistically significant for the chances of being among returnees. Respondents with higher education are less likely to have worked abroad compared to people with primary or lower education (reference category).

Unemployed young people are significantly more likely to plan to leave the country compared to those who have jobs. However, there is no significant statistical chance for unemployed to have emigration experience compared to employed. Economically inactive men and women are significantly more likely to have an experience with work abroad (employed-reference category).

Respondents from large families with more than two siblings are more likely to plan to look for a job abroad (reference category-having no siblings). However, they do not have statistically significant greater odds of having experience with work abroad. Young people who live in rented dwellings are more likely to have worked abroad. In this regard, labour experience abroad is considered a strategy for earning additional money through work abroad.

Respondents living outside the capital significantly more often plan to leave the country to work abroad. However, the place of residence is not significant for the actual emigration experience. The existence of significant disparities in Bulgaria between the capital Sofia and other types of place of residence, especially small towns and villages, increases the likelihood that young people not living in the capital will consider emigration an alternative way to find a better-paid job. The reason for the higher emigration intentions lies in the big differences between the capital and the countryside in terms of employment opportunities and living standards. The place of residence is a strong predictor of emigration intentions but not of real emigration experience. There is no statistically significant difference in emigration experience between young people from the capital and those from other types of place of residence (big/small city and village). The reasons for the discrepancy between intentions and actual experience with emigration will be further discussed on the regional and municipality levels.

According to the results from additional analyses, presented in Table 2 in 
Table 3. Respondents' region of birth and current place of residence (\%)

\begin{tabular}{lrrrrrrr}
\hline & \multicolumn{6}{c}{ Region of current place of residence } \\
\cline { 2 - 8 } Region of birth & $\begin{array}{c}\text { North- } \\
\text { west }\end{array}$ & $\begin{array}{c}\text { North- } \\
\text { central }\end{array}$ & $\begin{array}{c}\text { North- } \\
\text { east }\end{array}$ & $\begin{array}{c}\text { South- } \\
\text { west }\end{array}$ & $\begin{array}{c}\text { South- } \\
\text { central }\end{array}$ & $\begin{array}{c}\text { South- } \\
\text { east }\end{array}$ & Total \\
\hline Northwest & 434 & 5 & 2 & 25 & 0 & 1 & 467 \\
$\%$ & 97.75 & 3.09 & 1 & 5.17 & 0 & 0.48 & 25.96 \\
North-central & 7 & 152 & 5 & 9 & 0 & 0 & 173 \\
$\%$ & 1.58 & 93.83 & 2.5 & 1.86 & 0 & 0 & 9.62 \\
Northeast & 1 & 4 & 186 & 7 & 0 & 0 & 198 \\
$\%$ & 0.23 & 2.47 & 93.00 & 1.45 & 0 & 0 & 11.01 \\
Southwest & 2 & 0 & 1 & 415 & 0 & 0 & 418 \\
$\%$ & 0.45 & 0 & 0.5 & 85.74 & 0 & 0 & 23.24 \\
South-central & 0 & 0 & 3 & 11 & 300 & 2 & 316 \\
$\%$ & 0 & 0 & 1.5 & 2.27 & 100.00 & 0.96 & 17.57 \\
Southeast & 0 & 1 & 3 & 17 & 0 & 206 & 227 \\
$\%$ & 0 & 0.62 & 1.5 & 3.51 & 0 & 98.56 & 12.62 \\
Total & 444 & 162 & 200 & 484 & 300 & 209 & 1,80 \\
$\%$ & 100 & 100 & 100 & 100 & 100 & 100 & 100 \\
\hline
\end{tabular}

the Appendix, young people from the north-central region ${ }^{11}$ are more likely to have emigration experience than those living in the least developed region in the country, the northwest region. ${ }^{12}$ Emigration from Gabrovo, the most developed municipality in the region, is relatively high, at $5.5 \%$ inhabitants compared to $3.5 \%$ for Silistra [IME 2016]. The uneven level of development across municipalities in the same region is one difficulty for analysis on the regional level. The higher level of experience with emigration can be explained by the existence of

${ }^{11}$ The North-Central region in Bulgaria is a relatively poor region in the country. In 2016 the unemployment rate in this region was $10 \%$ compared to $9.4 \%$ for the country as a whole. There is strong variation in the rates of unemployment within the region, ranging from $5.7 \%$ in the municipality of Gabrovo to $15.8 \%$ in the municipality of Silistra. See EURES at: https://ec.europa.eu/eures/main.jsp?catId=9572\&acro=lmi\&mode=text\&recordLang= bg\&lang=bg\&parentId=\&countryId=BG\&regionId=BG0 (retrieved 15 October 2017).

${ }_{12}$ The Northwest region in Bulgaria is the poorest region in the country and also in the European Union. In 2016 the rate of unemployment was $17.6 \%$ compared to the national average of $9.4 \%$. See EURES at: https://ec.europa.eu/eures/main.jsp?countryId=BG\&ac ro=lmi\&show Region=true\&lang=bg\&mode=text\&regionId=BG0\&nuts2Code=BG32\&nu ts3Code=null\&catId=9574 (retrieved 15 October 2017). 
more universities in the north-central region. Universities are located in four municipalities in the north-central region: Gabrovo, Russe, Svistov, Tarnovo. There are also options for student mobility within the Erasmus programme and universities also develop different options for bilateral cooperation for students.

In contrast to the northwest region the existence of only one higher education institution contributes to the fact that this region is the most underdeveloped one in the country. According to the results in Table 3, this region has the highest rate of young people for whom the place of birth and the place of residence coincide; i.e. these people have the lowest geographical mobility. In this case, the poorer economic and educational conditions in the region and the poor resources of local people probably do not lead to a higher likelihood for emigration but rather lead people to fall into a poverty trap with a lack of clear prospects for improving their situation in life. In addition, at the time of the study, the lowest coincidence between place of birth and place of residence, as an indicator of higher geographic mobility, was recorded in the most developed region of the country, the southwest region.

\section{Discussion and conclusion}

In this analysis we investigated additional factors of emigration intentions and experience with emigration compared to previous research, such as the family situation of the young person and the young person's background family. We also compared the intention to emigrate with actual emigration experience. In some cases we found the effect of the same independent variable to be identical for the intention and experience of emigration, in other cases the effects were different or non-existent.

The conclusions that we can draw from the models regarding emigration intentions partly confirm the first hypothesis that the employment status of the respondents, particularly the unemployed status, increases the likelihood of the intentions to work abroad. Economic inactivity has a positive effect on the actual experience with work abroad.

The second hypothesis has been confirmed. Previous emigration experience increases emigration intentions irrespective of level of education and employment status. Previous emigration experience is the strongest predictor of emigration intentions. The explanation is that emigration experience has positive effects in both an economic and a broader social perspective, as has been documented in previous research [Martin and Radu 2009; Zaiceva and Zimmerman 2012]. The social remittances from experience with work abroad may include better language skills, labour market experience, better labour skills, and accumulated experience with living in a foreign country, and experiencing living away from the parents' family. All these could provide better opportunities for young people for future work and development. 
The third hypothesis was partly supported as valid only in the case of higher education and its impact on emigration experience. Secondary and higher education do not have any effect on emigration intentions. They are shared equally by all types of occupation among young people leaving education. But for the actual experience with emigration higher education has a negative effect, as young people with higher education are less likely to have emigration experience among the young people interviewed in the home country.

The fourth hypothesis is also partly supported. We hypothesised that living in a place other than the capital city Sofia increases both emigration intentions and experience. What we observed is that the place of residence is a strong predictor of emigration intentions but not of real emigration experience. Young people from large and small cities and villages more often have emigration intentions than those from the capital city of Sofia. Even before 1989, tremendous differences have existed between the capital and smaller towns and villages in Bulgaria in terms of employment opportunities, income, and living standards. At that time visa restrictions limited external migration. After the beginning of the democratic transformation in 1989, residential permissions were abolished. However, the differences between the capital city and the rest of the settlements in the country persist even nowadays. They are a strong push factor for youth labour migration.

The fifth hypothesis is confirmed. Men more often have emigration intentions and emigrate more often than women Gender remains statistically significant both for the emigration intentions and emigration experience of young people even after controlling for additional factors such as the family status of the respondents, education, and economic status.

The sixth hypothesis was about the profile of the returnees. We expected that young returnees would be more likely to come from economically deprived families and to have lower human and social capital. This has been partly supported by the results of our analysis, which showed that young people who have worked abroad and later returned to Bulgaria are more likely to be economically inactive and to live in a rented dwelling. The expectation that they come from families with more than two siblings was confirmed for emigration intentions, but not for the actual experience with emigration. Mihailov and Nollert [2017] showed in their study that when Bulgarian migrants return home from Switzerland, they often experience a decrease in social status or even end up unemployed. However, while abroad, their lower educational and vocational qualifications are compounded by poor linguistic skills, so that the only option open to them after completing their work contract is to return home. This also means that the less qualified young returnees may even exacerbate the youth unemployment problem in the home country. Thus, the successful labour market re-integration of inactive young people seems to be one of the most serious challenges for Bulgaria identified in our study. The profile of young Bulgarian returnee migrants described here can contribute to the policy debate about young people who are 
in the NEET group. This article identifies short-term labour migration as one possible explanation for the large numbers of NEETs in Bulgaria. Young people are motivated to work abroad due to existing East-West wage differences. After returning to their home country many of them look for their next job opportunity abroad instead of improving their education and qualifications, which in turn could improve their labour market chances in their home country. Low-skilled young people who return from working abroad see a partial improvement in their economic insecurity, but a disturbing finding in our analysis is that only one-third of the respondents who found their first job abroad after leaving formal education were employed at the time of the survey. In order to diminish the negative effect of young people's emigration from the country, it is necessary to take into account labour market needs and the educational profile of young people, not only in the country of their birth, but also in EU member states. The task that remains for academic research is to evaluate the effectiveness of labour activation and integration policies for specific target groups, especially with a focus on young Roma people, who form a disproportionally large share of NEETs in Bulgaria. National regional disparities also need to be more deeply investigated in the future and the interrelation between educational structure and job opportunities explained. We observed a higher rate of emigration experience in the region with more universities than in the poorest region of the country with no university.

There is a need for a differentiated approach to high-performing young people and to those who are exposed to the risks of becoming inactive, before lower educated young people. Emigration intentions are observed among young people with every educational background in our study, but it is less common among returnees with higher education. The policy implications of the results of our study touch upon problems that are on the (social/political) agenda in Bulgaria. The conclusions drawn from our analyses of labour migration intentions and experiences of young Bulgarians are also relevant for other European countries. Comparative analyses of youth emigration both as an intention and as a real experience, focusing on circular migration in Europe in times of economic crisis and on countries with high youth unemployment rates, remains an important goal for future research. The brain drain but also NEETs deserve equal attention from researchers and policymakers at the national and the European level because all EU citizens are part of a common educational and labour market.

Rumiana Stoilova is a professor at and the director of the Institute for the Study of Societies and Knowledge of the Bulgarian Academy of Sciences (since 2010 to the present). Her research focuses on social stratification and on the inequalities that shape chances over the life course, including labour market experiences and the relationship between social norms and individual agency. 
EliTsa Dimitrova is an associate professor in the Institute for Population and Human Studies of the Bulgarian Academy of Sciences. Her research interests are focused on fertility and family studies, social policy, and the health behaviours of young people, migration studies, and social-science methodology (qualitative and quantitative methods).

\section{References}

Boyle, P. J., H. Kulu, T. Cooke, V. Gayle and C. H. Mulder. 2008. 'Moving and Union Dissolution.' Demography 45: 209-222, https://doi.org/10.1353/dem.2008.0000.

Brzinsky-Fay, C. 2007. 'Lost in Transition? Labour Market Entry Sequences of School Leavers in Europe.' European Sociological Review 23 (4): 409-422, https://doi.org/10.1093/esr/jcm011.

Cadwallader, M. 1989. 'A Synthesis of Macro and Micro Approaches to Explaining Migration: Evidence from Inter-State Migration in the United States.' Geografiska Annaler. Series B, Human Geography 71 (2): 85-94, https://doi.org/10.1080/04353684.1989.11879588.

De Jong, G. F. and Robert W. Gardner. (eds) 1981. Migration Decision Making: Multidisciplinary Approaches to Microlevel Studies in Developed and Developing Countries. New York: Center for Cultural and Technical Interchange between East and West, Inc.

Dimitrova, E. and T. Kotzeva. 2013. 'Методът на събитийния анализ и приложението му в социология на жизнения път.' (The Event Analysis Method and Its Application in Life Course Sociology) Социологически проблеми / Sociological Problems 1-2: 91-117.

Eurofound. 2016. Exploring the Diversity of NEETs. Luxembourg: Publications Office of the European Union.

Eurostat. 1999. Guidelines and Table Programme for the Community Programme of Population and Housing Censuses in 2001. Vol. 1: Guidelines. Luxembourg: Office for Official Publications of the European Communities.

Fassmann, H. and C. Hintermann. 1997. Migrationspotential Ostmitteleuropa. Struktur und Motivation potentieller Migranten aus Polen, der Slowakei, Tschechien und Ungarn. ISR-Forschungsbericht 15. Vienna: Verlag der Österreichischen Akademie der Wissenschaften.

Gebel, M. and C. Noelke. 2011. The Transition from School to Work in Central and Eastern Europe: Theory and Methodology. Pp. 29-58 in Making the Transition. Education and Labour Market Entry in Central and Eastern Europe, edited by I. Kogan, C. Noelke and M. Gebel. Stanford, CA: Stanford University Press, https://doi.org/10.11126/ stanford/9780804775908.003.0002.

Hagen-Zanker, J. 2008. 'Why Do People Migrate? A Review of the Theoretical Literature.' Maastricht Graduate School of Governance Working Paper No. 2008/WP002. Retrieved 15 September 2017 (https://ssrn.com/abstract=1105657).

Haug, S. 2008. 'Migration Networks and Migration Decision-Making.' Journal of Ethnic and Migration Studies 34 (4): 585-605, https://doi.org/10.1080/13691830801961605.

Institute for Market Economics (IME). 2016. 'The Current State and Trends in Regional, Development: A General Review.' Retrieved 14 September 2017 (http://www.regionalprofiles.bg/en/summary_2016/).

Klabunde, A. and F. J. Willekens. 2016. 'Decision-making in Agent-based Models of Migration: State of the Art and Challenges.' European Journal of Population 32 (1): 73-97, https://doi.org/10.1007/s10680-015-9362-0.

Kley, S. 2011. 'Explaining the Stages of Migration within a Life-Course Framework.' European Sociological Review 27 (4): 469-486, https://doi.org/10.1093/esr/jcq020. 
Kogan, I. and W. Mueller. 2003. 'School-to-Work Transitions in Europe \& Analyses of the EU LFS 2000 Ad Hoc Module.' Mannheim: Mannheimer Zentrum fuer Europaeische Sozialforschung.

Kogan, I., F. Kalter, E. Liebau and Y. Cohen. 2011a. 'Individual Resources and Structural Constraints in Immigrants' Labour Market Integration.' Pp. 75-101 in A Life-Course Perspective on Migration and Integration, edited by M. Wingens, M. Windzio, H. de Valk and C. Aybek. Netherlands: Springer, https://doi.org/10.1007/978-94-007-1545-5_4.

Kogan, I., C. Noelke and M. Gebel. (eds) 2011b. ‘Making the Transition. Education and Labour Market Entry in Central and Eastern Europe.' Standford, CA: Stanford University Press, https://doi.org/10.11126/stanford/9780804775908.001.0001.

Kogan, I. 2012. 'Tertiary Education Landscape and Labour Market Chances of the Highly Educated in Central and Eastern Europe.' European Sociological Review, Special Issue: Central and Eastern Europe-Higher Education and Labour Markets in Transition 28 (6): 701-703, https://doi.org/10.1093/esr/jcs062.

Levitt, P. 2001. The Transnational Villagers. Berkeley and Los Angeles, CA: University of California Press.

Manchevat, M. and E. Troeva. 2011. 'Migrations to and from Bulgaria: The State of Research.' Pp. 13-61 in Migrations, Gender and Intercultural Interactions in Bulgaria, edited by M. Hajdinjak. Sofia: International Center for Minority Studies and International Relations.

Marinov, V. 2007. 'Международната трудова миграция: Икономически аспекти.' (International Labour Migration: Economic Aspects) Pp. 4-57 in Научни трудове/ Nauchni trudove. Sofia: UNSS.

Markova, E. 2010. 'Effects of Migration on Sending Countries: Lessons from Bulgaria.' GreeSE Paper No 35, Hellenic Observatory Papers on Greece and Southeast Europe. London: The Hellenic Observatory. Retrieved 15 October 2017 (http://eprints.lse.ac.uk/28438/1/GreeSE_No35.pdf).

Martin, R. and D. Radu. 2009. 'Return Migration: The Experience of Eastern Europe.' Paper presented at the 24th National Conference of Labour Economics at the Italian Association of Labour Economists, Sassari.

Mayer, K.-U. 2009. 'New Directions in Life Course Research.' Annual Review of Sociology 35: 413-433, https://doi.org/10.1146/annurev.soc.34.040507.134619.

Migration and Migration Behaviour of the Population. 2012. 'Миграция и миграционно поведение на населението. Извадкови изследвания. Том 4, книга 2. София: НСИ.' Representative Studies. Vol. 4, book 2. Sofia: National Statistical Institute.

Mihailov, D. and M. Nollert 2017. 'Linking Social Inequalities and Migration.' Pp. 61-89 in Migration and Transnationalism Between Switzerland and Bulgaria, edited by M. Richter, P. Ruspini, D. Mihailov, V. Mintchev and M. Nollert. New York: Springer International Publishing, https://doi.org/10.1007/978-3-319-31946-9_3.

Minchev, V. and V. Boshnakov. 2006a. ‘Return Migration's Profile and Experience: Empirical Evidence from Bulgaria.' The wiiw Balkan Observatory, Working Papers 065. Retrieved 15 October 2017 (https://wiiw.ac.at/return-migration-s-profile-andexperience-empirical-evidence-from-bulgaria-dlp-3243.pdf).

Minchev, V. and V. Boshnakov. 2006b. 'Икономика на българската емиграцияемпирични оценки.' (Economy of Bulgarian Emigration: Empirical Evaluations) Икономическа мисбл/Economic Thought 2: 23-47.

Mitev, P. E. and S. Kovacheva. 2014. Младите хора в европейска България - социологически nopmpem. (Young People in European Bulgaria: A Sociological Portrait) Sofia: Friedrich Ebert Foundation.

Neto, F. and E. Mullet. 1998. 'Decision-making as Regards Migration: Wage Differential, 
Job Opportunity, and the Network Effect.' Acta Psychologica 98 (1): 57-66, https:// doi.org/10.1016/S0001-6918(97)00035-8.

Nivalainen, S. 2004. 'Determinants of Family Migration: Short Moves vs Long Moves.' Journal of Population Economics 17: 157-175, https:// doi.org/10.1007/s00148-003-0131-8.

Noelke, C., M. Gebel and I. Kogan. 2012 `Uniform Inequalities: Institutional Differentiation and the Transition from Higher Education to Work in Post-socialist Central and Eastern Europe.' European Sociological Review, Special Issue: Central and Eastern Europe-Higher Education and Labour Markets in Transition 28 (6): 704-716.

Rangelova, R., Y. Kalchev, K. Vladimirova, V. Minchev, V. Boshnakov and S. Blazheva. 2006. 'Gender Dimension of Bulgaria's New Migration: Policy Implications.' Economic Studies 15 (1): 43-66.

Robert, P. and E. Saar. 2012. 'Learning and Working: The Impact of the "Double Status Position" on the Labour Market Entry Process of Graduates in CEE Countries.' European Sociological Review, Special Issue: Central and Eastern Europe-Higher Education and Labour Markets in Transition 28 (6): 742-754, https://doi.org/10.1093/esr/jcr091.

Söhn, J. 2011. 'Immigrants' Educational Attainment. A Closer Look at the Age-atMigration Effect.' Pp. 27-53 in A Life-course Perspective on Migration and Integration, edited by M. Wingens, M. Windzio and H. de Valk. Dordrecht u.a.: Springer.

Statistical Yearbook. 2016. Sofia: National Statistical Institute.

Stoilova, R. 2016. 'The Welfare State in the Context of the Global Financial Crisis: Bulgaria-Between Financial Stability and Political Uncertainty.' Pp. 59-78 Challenges to European Welfare Systems, edited by K. Schubert, P. de Vilotta and J. Kuhlmann. Cham: Springer International Publishing, https://doi.org/10.1007/978-3-319-07680-5_4.

Stoilova, R. and K. Haralampiev. 2010. 'Gender neravenstva i rolia na darzavata za tiahnoto namaliavane, Mezdunaroden sravnitelen analiz.' (Gender Inequalities and the Role of the State in Their Decrease. An International Comparison) Pp. 349-369 in Blagopoluchie I doverie. Bulgaria v Evropa. Sravnitelni analizi po Evropeiskoto socialno izsledvane 2006/2009, edited by N. Tilkidziev. Sofia: Iztok-Zapad.

Stoilova, R. and K. Slavova. 2006. 'Spatial Mobility and Gender Inequality.' Sociological problems. Special Issue, Trajectories of Contemporary Sociology in Bulgaria, XVI ISA World Congress: 190-280.

Tamesberger, D. 2015. 'A Multifactorial Explanation of Youth Unemployment and the Special Case of Austria.' International Social Security Review 68 (1): 23-45, https://doi.org/10.1111/issr.12058.

Vavrečková, J. and I. Baštýř. 2009. The Effect of Brain Drain in the Czech Republic and Earnings Motivation for Qualified Specialists to Work Abroad. Prague: Research Institute for Labour and Social Affairs. Retrieved 15 October 2017 (http://praha.vupsv.cz/Fulltext/vz_303en.pdf).

Wallace, C. 2002. 'Opening and Closing Borders: Migration and Mobility in East-Central Europe.' Journal of Ethnic and Migration Studies 28 (4): 603-625, https://doi.org/10.1080/1369183021000032227.

Wingens, M., H. de Valk, M. Windzio and C. Aybek. 2011. 'The Sociological Life Course Approach and Research on Migration and Integration.' Pp. 1-27 in A Life-Course Perspective on Migration and Integration, edited by M. Windzio, H. de Valk and C. Aybek. Netherlands: Springer, https://doi.org/10.1007/978-94-007-1545-5_1.

World Bank. 2012. Profile of Migration and Remittances: Bulgaria. Washington, DC: World Bank Group. Retrieved 15 October 2107 (http://documents.worldbank.org/curated/ en/704231467995384957 / Profile-of-migration-and-remittances-Bulgaria). 
World Bank. 2017. Migration and Remittances Factbook. 2016. New York: World Bank. Retrieved 15 October 2017 (https://siteresources.worldbank.org/INTPROSPECTS/ Resources/334934-1199807908806/4549025-1450455807487/Factbookpart1.pdf).

Zaiceva, A. and K. Zimmermann. 2012. 'Returning Home at Times of Trouble? Return Migration of EU Enlargement Migrants during the Crisis.' IZA Discussion Paper No. 7111. Retrieved 15 October 2107 (http://ftp.iza.org/dp7111.pdf). 


\section{Appendix}

Table 4. 'What was the purpose of your longest stay abroad after you ended your formal education?' (\%)

\begin{tabular}{lcc}
\hline & Freq. & $\%$ \\
\hline Related to work & 156 & 44.6 \\
Related to family & 97 & 27.7 \\
Tourism & 79 & 22.6 \\
Related to education or training & 11 & 3.1 \\
Other & 7 & 2.0 \\
Total & 350 & 100 \\
\hline
\end{tabular}

Table 5. Duration of employment abroad (among those who have returned)

\begin{tabular}{lccccc}
\hline & Freq. & Mean & $\begin{array}{c}\text { Stand. } \\
\text { dev. }\end{array}$ & Min. & Max. \\
\hline Duration of the 1st job abroad & 34 & 1.06 & 1.09 & 0.25 & 4.08 \\
Duration of the 2nd job abroad & 29 & 0.95 & 0.87 & 0.17 & 3.25 \\
Duration of the 3rd job abroad & 20 & 0.83 & 0.65 & 0.25 & 2.50 \\
\hline
\end{tabular}

Table 6. Time elapsed between the end of formal education and finding a first (next) job in a foreign country

\begin{tabular}{lccccc}
\hline & Freq. & Mean & $\begin{array}{c}\text { Stand. } \\
\text { dev. }\end{array}$ & Min. & Max. \\
\hline $\begin{array}{l}\text { Time elapsed between the end of } \\
\text { formal education and first job in } \\
\text { a foreign country }\end{array}$ & 38 & 0.04 & 0.04 & 0.00 & 0.08 \\
$\begin{array}{l}\text { Time elapsed between the end of } \\
\text { formal education and second job } \\
\text { in a foreign country }\end{array}$ & 31 & 1.03 & 0.87 & 0.17 & 3.17 \\
$\begin{array}{l}\text { Time elapsed between end of } \\
\text { formal education and third job } \\
\text { in a foreign country }\end{array}$ & 20 & 1.30 & 0.62 & 0.50 & 2.83 \\
\hline
\end{tabular}


Table 7. Economic status of respondents at the time of the survey who had obtained their first job abroad (\%)

\begin{tabular}{lcc}
\hline & No. & Percentage \\
\hline Ending in employment & 28 & 33 \\
Ending in inactivity & 16 & 19 \\
Ending in unemployment & 17 & 20 \\
Instability & 17 & 20 \\
Seasonal work & 8 & 9 \\
Total & 86 & 100 \\
\hline
\end{tabular}


Table 8. Descriptive statistics of the variables included in the model of the presence/ absence of the intention to emigrate in order to work abroad-part one

\begin{tabular}{|c|c|c|c|}
\hline & \multicolumn{3}{|c|}{ Migration intentions (\%) } \\
\hline & Yes & No & Total \\
\hline \multicolumn{4}{|l|}{ Age } \\
\hline 15-24 years old & 80.6 & 19.4 & 100 \\
\hline 25-34 years old & 88.1 & 11.9 & 100 \\
\hline Total & 82.9 & 17.1 & 100 \\
\hline \multicolumn{4}{|l|}{ Gender } \\
\hline Male & 78.3 & 21.8 & 100 \\
\hline Female & 87.4 & 12.6 & 100 \\
\hline Total & 82.9 & 17.1 & 100 \\
\hline \multicolumn{4}{|l|}{ Ethnicity } \\
\hline Bulgarian & 84.5 & 15.5 & 100 \\
\hline Non-Bulgarian & 78.1 & 21.9 & 100 \\
\hline Total & 82.9 & 17.1 & 100 \\
\hline \multicolumn{4}{|l|}{ Education } \\
\hline Primary/basic & 79 & 21 & 100 \\
\hline Secondary & 81.9 & 18.1 & 100 \\
\hline $\mathrm{BA} / \mathrm{MA} / \mathrm{PhD}$ degree & 88.4 & 11.6 & 100 \\
\hline Total & 82.9 & 17.1 & 100 \\
\hline \multicolumn{4}{|l|}{ Employment status of $\mathrm{R}$} \\
\hline Employed & 85.2 & 14.8 & 100 \\
\hline Unemployed & 76.1 & 23.9 & 100 \\
\hline Economically inactive & 89.4 & 10.6 & 100 \\
\hline Total & 82.9 & 17.1 & 100 \\
\hline \multicolumn{4}{|c|}{ Previous migration experience } \\
\hline No & 85.4 & 14.6 & 100 \\
\hline Yes & 51.9 & 48.1 & 100 \\
\hline Total & 82.9 & 17.1 & 100 \\
\hline \multicolumn{4}{|l|}{ Family status } \\
\hline No partner & 81.4 & 18.6 & 100 \\
\hline Cohabitation & 83.8 & 16.2 & 100 \\
\hline Married & 88.1 & 11.9 & 100 \\
\hline Total & 82.9 & 17.1 & 100 \\
\hline
\end{tabular}


Table 8. Descriptive statistics of the variables included in the model of the presence/ absence of the intention to emigrate in order to work abroad-part two

\begin{tabular}{|c|c|c|c|}
\hline & \multicolumn{3}{|c|}{ Migration intentions (\%) } \\
\hline & Yes & No & Total \\
\hline \multicolumn{4}{|l|}{ Number of children } \\
\hline No children & 81.6 & 18.4 & 100 \\
\hline Have children & 88.0 & 12.0 & 100 \\
\hline Total & 82.9 & 17.1 & 100 \\
\hline \multicolumn{4}{|l|}{ Place of residence } \\
\hline Sofia & 90.3 & 9.7 & 100 \\
\hline Big city & 83.0 & 17.0 & 100 \\
\hline Small city & 81.3 & 18.7 & 100 \\
\hline Village & 80.9 & 19.1 & 100 \\
\hline Total & 82.9 & 17.1 & 100 \\
\hline \multicolumn{4}{|l|}{ Household } \\
\hline Lives with parents & 82.1 & 17.9 & 100 \\
\hline Lives in own dwelling & 87.3 & 12.7 & 100 \\
\hline $\begin{array}{l}\text { Lives in rented dwelling/ } \\
\text { with other people }\end{array}$ & 82.1 & 17.9 & 100 \\
\hline Total & 82.9 & 17.1 & 100 \\
\hline \multicolumn{4}{|l|}{ Father's employment status } \\
\hline Employed & 83.1 & 16.9 & 100 \\
\hline $\begin{array}{l}\text { Unemployed/econ. inactive/ } \\
\text { no father }\end{array}$ & 82.3 & 17.7 & 100 \\
\hline Total & 82.8 & 17.2 & 100 \\
\hline \multicolumn{4}{|l|}{ Mother's employment status } \\
\hline Employed & 83.5 & 16.5 & 100 \\
\hline $\begin{array}{l}\text { Unemployed/econ. inactive/ } \\
\text { no mother }\end{array}$ & 81.4 & 18.6 & 100 \\
\hline Total & 82.9 & 17.1 & 100 \\
\hline \multicolumn{4}{|l|}{ Number of siblings } \\
\hline No siblings & 86.2 & 13.8 & 100 \\
\hline 1 sibling & 83.6 & 16.4 & 100 \\
\hline $2+$ siblings & 77.7 & 22.3 & 100 \\
\hline Total $9 \%$ & 82.9 & 17.1 & 100 \\
\hline
\end{tabular}


Table 9. Descriptive statistics of the variables included in the model for presence/ absence of experience with work abroad after leaving formal education-part one

\begin{tabular}{|c|c|c|c|}
\hline & \multicolumn{3}{|c|}{ Migration experience (\%) } \\
\hline & Yes & No & Total \\
\hline \multicolumn{4}{|l|}{ Age } \\
\hline 15-24 years old & 93.0 & 7.0 & 100 \\
\hline 25-34 years old & 91.5 & 8.5 & 100 \\
\hline Total & 92.5 & 7.5 & 100 \\
\hline \multicolumn{4}{|l|}{ Gender } \\
\hline Male & 90.2 & 9.8 & 100 \\
\hline Female & 94.9 & 5.1 & 100 \\
\hline Total & 92.6 & 7.4 & 100 \\
\hline \multicolumn{4}{|l|}{ Ethnicity } \\
\hline Bulgarian & 93.3 & 6.7 & 100 \\
\hline Non-Bulgarian & 90.4 & 9.6 & 100 \\
\hline Total & 92.6 & 7.4 & 100 \\
\hline \multicolumn{4}{|l|}{ Education } \\
\hline Primary/basic & 90.6 & 9.5 & 100 \\
\hline Secondary & 92.8 & 7.2 & 100 \\
\hline BA/MA/PhD degree & 93.7 & 6.3 & 100 \\
\hline Total & 92.6 & 7.4 & 100 \\
\hline \multicolumn{4}{|l|}{ Employment status of $\mathrm{R}$} \\
\hline Employed & 93.4 & 6.6 & 100 \\
\hline Unemployed & 92.0 & 8.0 & 100 \\
\hline Economically inactive & 90.57 & 9.43 & 100 \\
\hline Total & 92.6 & 7.4 & 100 \\
\hline \multicolumn{4}{|l|}{ Family status } \\
\hline No partner & 93.1 & 6.9 & 100 \\
\hline Cohabitation & 93.4 & 6.6 & 100 \\
\hline Married & 89.6 & 10.4 & 100 \\
\hline Total & 92.6 & 7.4 & 100 \\
\hline \multicolumn{4}{|l|}{ Number of children } \\
\hline No children & 92.8 & 7.2 & 100 \\
\hline Have children & 91.7 & 8.3 & 100 \\
\hline Total & 92.6 & 7.4 & 100 \\
\hline
\end{tabular}


Table 9. Descriptive statistics of the variables included in the model for presence/ absence of experience with work abroad after leaving formal education-part two

\begin{tabular}{|c|c|c|c|}
\hline & \multicolumn{3}{|c|}{ Migration experience (\%) } \\
\hline & Yes & No & Total \\
\hline \multicolumn{4}{|l|}{ Place of residence } \\
\hline Sofia & 93.7 & 6.4 & 100 \\
\hline Big city & 92.6 & 7.4 & 100 \\
\hline Small city & 93.5 & 6.5 & 100 \\
\hline Village & 91.2 & 8.9 & 100 \\
\hline Total & 92.6 & 7.4 & 100 \\
\hline \multicolumn{4}{|l|}{ Household } \\
\hline Lives with parents (ref.) & 93.4 & 6.6 & 100 \\
\hline Lives in own dwelling & 91.0 & 9.0 & 100 \\
\hline $\begin{array}{l}\text { Lives in rented dwelling/ } \\
\text { with other people }\end{array}$ & 90.2 & 9.8 & 100 \\
\hline Total & 92.6 & 7.4 & 100 \\
\hline \multicolumn{4}{|l|}{ Father's employment status } \\
\hline Employed & 93.1 & 6.9 & 100 \\
\hline $\begin{array}{l}\text { Unemployed/econ. inactive/ } \\
\text { no father }\end{array}$ & 91.4 & 8.6 & 100 \\
\hline Total & 92.6 & 7.4 & 100 \\
\hline \multicolumn{4}{|l|}{ Mother's employment status } \\
\hline Employed & 93.4 & 6.6 & 100 \\
\hline $\begin{array}{l}\text { Unemployed/econ. inactive/ } \\
\text { no mother }\end{array}$ & 90.5 & 9.5 & 100 \\
\hline Total 9\%) & 92.6 & 7.4 & 100 \\
\hline \multicolumn{4}{|l|}{ Number of siblings } \\
\hline No siblings & 94.0 & 6.0 & 100 \\
\hline 1 sibling & 92.3 & 7.7 & 100 \\
\hline $2+$ siblings & 91.9 & 8.1 & 100 \\
\hline Total & 92.6 & 7.4 & 100 \\
\hline
\end{tabular}

